\title{
Phosphorus, Potassium and Phytohormones Promote Chlorophyll Production Differently in Two Cotton (Gossypium hirsutum) Varieties Grown in Hydroponic Nutrient Solution
}

\author{
Adebusoye O. Onanuga (Corresponding author) \\ Department of Biology, Dalhousie University, 1355 Oxford Street, Halifax \\ Nova Scotia, B3H 4J2. Canada \\ Tel: 1-902-494-2753 E-mail: Adebusoye.Onanuga@Dal.Ca
}

Ping'an Jiang

College of Natural Resources and Environmental Sciences, Xinjiang Agricultural University

No 42 Nanchang Road, Urumqi 830052, China

Tel: 86-130-779-998-656_E-mail: jiang863863@sina.com

Sina Adl

Department of Biology, Dalhousie University, 1355 Oxford Street

Halifax, Nova Scotia, B3H 4J2. Canada

Tel: 1-902-494-2753 E-mail: sadl@Dal.Ca

Received: July 1, $2011 \quad$ Accepted: July 12, $2011 \quad$ Online Published: December 21, 2011

doi:10.5539/jas.v4n2p157

URL: http://dx.doi.org/10.5539/jas.v4n2p157

\begin{abstract}
The effectiveness of phosphorus (P), potassium (K), indole-3-acetic acid (IAA), gibberellic acid $\left(\mathrm{GA}_{3}\right)$, zeatin (Z) and their combinations on chlorophyll $\mathrm{a}, \mathrm{b}$ and total chlorophyll production was investigated in the hydroponic nutrient solution. The cotton plants were cropped without hormones application in different levels of $\mathrm{P}$ and $\mathrm{K}$ in the first cropping and with hormones application in the second cropping in high level of PK. In the first cropping, low K and high PK significantly influenced formation of chlorophyll a, b and ab from 83 to 91 days after planting (DAT) while the application of $\mathrm{GA}_{3}$, IAA, $\mathrm{Z}$ and IAA $\times \mathrm{GA}_{3} \times 2 \mathrm{Z}$ treatments significantly increased chlorophyll a, b and ab only at 80 DAT. However, two cotton varieties planted in two cropping seasons expressed different abilities in time to promote chlorophyll formation.
\end{abstract}

Keywords: Indole-3-acetic acid, Gibberellic acid, Zeatin, Chlorophyll, Hydroponic, Phosphorus, Potassium, Cotton

\section{Introduction}

Plant hormones have been known to regulate the physiological process in plant. Greening in plant indicates a well being of a plant. Among the phytohormones, cytokinins (zeatin) regulate various growth and development process in plants. Fletcher and McCullagh (1971) reported that cytokinins played an important role in the chlorophyll formation. It is well documented that cucumber plant (Cucumis sativus cv Brumex) pretreated in the dark with cytokinins promote chlorophyll formation during subsequent continuous illumination. Furthermore, Mitsuru and Hideo (1978) made an assertion that the pre-treated cotyledon of cucumber with Benzylaminopurine (BA), Gibberellic acid $\left(\mathrm{GA}_{3}\right)$, and Indole-3-acetic acid (IAA) stimulated chlorophyll formation. Several workers have reported that cytokinin effect on chlorophyll formation in light depends on the length of time of dark preincubation with cytokinins (Fletcher and McCullagh, 1971; Ford et al., 1977; Uheda and Kuraishi, 1977; Dei and Tsuji, 1978). However, cytokinins (zeatin) is one of the plant hormones known to promote greening (chlorophyll synthesis) in plants using light as a final step catalyzed by nicotinamide adenine dinucleotide 
phosphate (NADPH) (Koski et al., 1951; Griffiths 1978; Apel et al., 1980; Yoshiki et al 2003).

Plant nutrients especially Nitrogen, Phosphorus and Potassium (NPK) are primary nutrients elements that plants require in large quantity for the physiological development. The physiological changes in plant status may be resulted from the measured changes in leaf pigmentation e.g. chlorophyll a, chlorophyll b (Fridgen and Varco 2004). Studies have indicated that less than optimum $N$ availability required for plants lead to reduced total chlorophyll concentration in cotton leaves (Thomas and Gausman, 1977; Longstreth and Nobel 1980 Everitt et al., 1985). It has been demonstrated by Oosterhuis and Bednarz (1997) that chlorophyll a and total chlorophyll concentration were reduced in cotton due to K deficiency. Lamrani et al., (1996) reported that high levels of K nutrition promoted formation of chlorophyll $\mathrm{a}$ and $\mathrm{b}$ in cucumber plant (Cucumis sativus cv Brumex). It has been reported that adequate supply of potassium nutrient increase chlorophyll content of plants (Stromberg 1960; Fletcher et al., 1982; Maples et al., 1988; Duli et al., 2001). From the previous studies, phosphorus needed for chlorophyll formation received less attention. It is reported in the literature that potassium and cytokinins stimulate chlorophyll synthesis in plants. The main objective of this research was to investigate the influence of exogenous application of phytohormones ( $\mathrm{GA}_{3}, \mathrm{IAA}, \mathrm{Z}$ and their combinations) in chlorophyll production.

\section{Materials and Methods}

\subsection{First cropping}

Nutrients solution experiment: The two cotton varieties (Zhong Mian 36 and Xin Luo Zao 13) were cultivated in the quartz sand. The roots of cotton seedlings were allowed to grow up to $8-10 \mathrm{~cm}$, before transplanting into nutrient solution pot of $6 \mathrm{~L}$.

These specifications were followed: The day time temperature was kept at a range of $20-35^{\circ} \mathrm{C}$, the surrounding sunlight was maintained above 12 hours, there was a constant supply of oxygen and the room temperature was recorded. The nutrient solutions were Hoagland and micro anion nutrients, the low $\mathrm{P}$ level was $0.05 \times 10^{-3} \mathrm{molL}^{-1}$, the low K level was $1 \times 10^{-3} \mathrm{molL}^{-1}$ and the high PK level were $1 \times 10^{-3}$ and $6 \times 10^{-3} \mathrm{molL}^{-1}$ at $\mathrm{pH} 6.5$ (Table 1). At every nutrient change, one cotton plant from each of three treatments of the two cotton varieties of the experiment replicated three times $(3 \times 2 \times 3=18)$ to measure chlorophyll $\mathrm{a}, \mathrm{b}$ and $\mathrm{ab}$.

\subsection{Second cropping}

In the second cropping of the experiment, the cultivation and other necessary measures were as in the first cropping. The exogenous hormones concentration were applied at 36 and 67 days after transplanting to Hoagland complete nutrients fluid by spraying on cotton leave at single rate of $0,50,40$ and $50 \mu \mathrm{gL}^{-1}$ for untreated pots, indole-3-acetic acid, gibberellic acid and zeatin, respectively and combined rate of 50IAA*40GA*50Z, 100IAA*40GA*50Z, 50IAA*80GA*50Z, 50IAA*40GA*100Z and $100 \mathrm{IAA}^{*} 80 \mathrm{GA} * 100$ supply with the highest PK nutrient levels of $1 \times 10^{-3}$ and $6 \times 10^{-3} \mathrm{molL}^{-1}$ at $\mathrm{pH} 6.5$ in the hydroponics solution (Table 1). At every nutrient change, nine cotton were selected from the each of the two varieties, replicated three times $(9 * 3 * 2=54)$ so as to measure chlorophyll $\mathrm{a}, \mathrm{b}$ and $\mathrm{ab}$.

\subsection{Chlorophyll measurement}

$0.5 \mathrm{~g}$ of leaf pigment was extracted from cotton leaves. $8 \mathrm{ml}$ of 80 percent Acetone was added, and incubated for $12-14$ hours. $1 \mathrm{ml}$ solution was taken out of the latter, $9 \mathrm{ml}$ of 80 percent acetone was added, and then centrifuge. $10 \mathrm{ml}$ of 80 percent acetone was added to the supernatant. Thereafter, measured with spectrophotometer at wavelength of $663 \mathrm{~nm}$ and $645 \mathrm{~nm}$ for chlorophyll a and b, respectively.

\subsection{Data Analysis}

The data was analyzed using general linear model (GLM) with SPSS software version 15. Least significance differences using Duncan's multiple range test (DMRT) for separation of treatment and variety means. Correlation statistical analysis was used to compare chlorophyll $\mathrm{a}, \mathrm{b}$ and ab formation in the first and second cropping of the experiment.

\section{Results}

\subsection{First Cropping Experiment}

Effect of phosphorus $(P)$, potassium $(K)$ and PK treatments on cotton chlorophyll $a, b$ and ab production grown in hydroponics nutrients solution.

The effects of low P, low K and high PK treatments on chlorophyll a are shown in Table 2. The high PK treatment significantly produced the highest chlorophyll a with the value of $1.92 \mu \mathrm{g} \mathrm{ml}^{-1}$ which was insignificant to low $\mathrm{K}$ treatment with value of $1.23 \mu \mathrm{g} \mathrm{ml}^{-1}$. The low $\mathrm{P}$ treatment gave the lowest chlorophyll a production 
$\left(0.456 \mathrm{~g} \mathrm{ml}^{-1}\right)$ which was insignificant to low $\mathrm{K}$ treatment at 83 days after transplanting (DAT). However, at 91 DAT, low $\mathrm{K}$ and high PK treatments significantly produced more chlorophyll a $\left(1.76\right.$ and $1.90 \mu \mathrm{g} \mathrm{ml}^{-1}$, respectively) than low $\mathrm{P}$ treatment with value of $0.504 \mathrm{~g} \mathrm{ml}^{-1}$. As from 104 to $148 \mathrm{DAT}$, there was no significant difference in the ability of the treatments applied to promote chlorophyll formation.

The effects of low P, low K and high PK treatments on chlorophyll $b$ and ab production are summarized in Table 3 and 4. At 83 DAT, it is obvious that low $\mathrm{K}$ and high PK treatments enhanced more chlorophyll b production than low P treatment. Similar performance was observed at 91 DAT. It is noteworthy that treatments applied had no effect on chlorophyll formation from 104 to 148 DAT. The same result was obtained for chlorophyll ab.

\subsection{Varieties}

Figure 1a shows that Xin Cotton variety significantly influenced more chlorophyll a production than Zhong cotton variety at 83 DAT. The two cotton varieties produced no change in chlorophyll a production from 91 to 120 DAT. However, at 148 DAT, Zhong cotton variety proved superior to Xin cotton variety in chlorophyll a production.

Figure $1 \mathrm{~b}$ reveals that Xin Cotton variety produced more chlorophyll $\mathrm{b}$ than Zhong cotton variety at 83 and 104 DAT. As from 91 to 120 DAT, the two varieties were not significantly different from each other in chlorophyll b production. Zhong cotton variety performed better than Xin cotton variety at 148 DAT. The same result was obtained for the two varieties in relation to chlorophyll a and chlorophyll ab production (Fig 1c).

\subsection{Second Experiment}

3.3.1 Effect of hormones treatment on cotton plants chlorophyll a, b and ab production grown in hydroponics nutrient solution

Table 5 summarizes the effect of hormones on chlorophyll a production grown hydroponically in high level of phosphorus and potassium nutrients. The single applied IAA and $Z$ treated plants significantly enhanced chlorophyll a production, but there was no significant difference between plants treated with IAA, $Z$ and those plants treated with $\mathrm{GA}_{3}$, IAA $\times \mathrm{GA}_{3} \times 2 \mathrm{Z}$ while combined use of 2IAA with $\mathrm{GA}_{3}$ and $\mathrm{Z}$ including untreated plants gave the least chlorophyll a production at 80 DAT. Surprisingly, at 90 DAT, the untreated pot significantly gave more chlorophyll a production than other treatments although untreated pot was insignificant to IAA and 2IAA x $\mathrm{GA}_{3} \times \mathrm{Z}$ treated plants.

Effect of hormones on chlorophyll $b$ production grown in hydroponic nutrient solution of high level phosphorus and potassium nutrients are given in Table 5. The combined application of IAA x GA $\times 2 Z$ caused significant chlorophyll $b$ production than other treatments although combined hormones application of IAA $x \mathrm{GA}_{3} \times 2 \mathrm{Z}$ was the same as with a single applied IAA, $\mathrm{GA}_{3}$ and $\mathrm{Z}$ hormone application. However, combined use of 2IAA $x \mathrm{GA}_{3}$ $\mathrm{x} \mathrm{Z}$ including untreated plants gave the least chlorophyll $\mathrm{b}$ formation at 80 DAT. Thereafter, at 90 DAT, amazingly, untreated plants had significantly more chlorophyll $b$ content than other treatments but the effect was the same as with IAA treated plants.

The effect of hormones on chlorophyll ab production grown in hydroponics nutrients solution of high level phosphorus and potassium are presented in Table 5. The single hormone application of IAA, $\mathrm{Z}$ and combined hormone application of IAA $\times \mathrm{GA}_{3} \times 2 \mathrm{Z}$ gave the highest chlorophyll ab production than the other treatments but these treatments (IAA, $\mathrm{Z}$, and IAA $\times \mathrm{GA}_{3} \times 2 \mathrm{Z}$ ) were insignificant to single hormone application of $\mathrm{GA}_{3}$ at 80 DAT. However, at 90 DAT, control experiment had more chlorophyll ab than other treated pots, but there was no significant difference between control and either IAA or 2IAA $\times \mathrm{GA}_{3} \times \mathrm{Z}$ treated pots.

\subsection{Varieties}

Figures $2 \mathrm{a}, 2 \mathrm{~b}$ and $2 \mathrm{c}$ show that high content of chlorophyll formation was observed at the beginning of the experiment and decreased downward toward the end of the experiment. The Zhong cotton variety produced significantly more chlorophyll a, b and ab than Xin cotton variety at 80 DAT. Beyond 80 DAT, Zhong cotton variety still proved superior to Xin cotton variety in chlorophyll $b$ production but it apparently appeared the same for the two varieties in chlorophyll a and ab production (Fig.2a, 2b and 2c).

3.5 Correlation co-efficient relating low P, low $K$ and high PK plant treatments at 148 DAT to hormones (IAA, $\mathrm{GA}_{3}, \mathrm{Z}$ and their combinations) plant treatments at high level of $P K$ at $90 \mathrm{DAT}$

The correlation co-efficient relating first and second crop performances are given in Table 6. There was no relationship between the first cropping experiment and the second cropping experiment. Chlorophyll a and ab formation in the first cropping were not related to chlorophyll a and ab formation in the second cropping while chlorophyll b was negatively insignificant $(\mathrm{r}=-0.005)$. 


\section{Discussion}

The low K and high PK treated plants enhanced chlorophyll a, b and ab production at 83 and 91 DAT. This confirms the report stated earlier that high levels of $\mathrm{K}$ nutrition promoted formation of chlorophyll $\mathrm{a}$ and $\mathrm{b}$ in cucumber (Cucumis sativus cv Brunex) leaves (Lamrani et al., 1996). Duli et al., (2001) also confirmed that K deficient in cotton is associated with low chlorophyll content. Beyond 91 days after transplanting, the nutrients applied did not have a significant effect. However, variety differences were noted at 83 DAT and 148 DAT for chlorophyll a and ab, Xin cotton variety performed better than Zhong cotton variety at 83 DAT, reversed was the case at 148 DAT, Zhong cotton variety outclassed Xin cotton variety. Nevertheless, differences between the two varieties for chlorophyll b production was also observed at 83 and 104 DAT, where Xin cotton outclassed Zhong cotton variety. The opposite observation was seen at 148 DAT. This agrees with finding of Cassman et al., (1989) that different varieties exhibited variations in nutrients efficiency utilization such as $\mathrm{K}$.

Single hormone application of IAA, Z, GA 3 and combined hormone application of IAA x GA $\mathrm{G}_{3} 2 \mathrm{Z}$ significantly increased chlorophyll a, $\mathrm{b}$ and ab at 80 DAT. However, Mitsuru and Hideo (1978) reported that pre-treatment of cotyledons with BA, $\mathrm{GA}_{3}$, or IAA stimulates chlorophyll formation by subsequent illumination. Fletcher and McCullagh. (1971); Roger and Hideo (1982); Yoshiki et al., (2003) reported that cytokinins (Zeatin) have an important role in the formation of chlorophyll. Beyond 80 DAT, the treatments failed to promote chlorophyll formation; this could be due to another hormone concentrations added at 67 DAT.

Nevertheless, there were obvious differences between varieties in chlorophyll production. Zhong cotton produced greener pigment (Chlorophyll a, b and ab) than Xin cotton; this could be caused by genotypic differences between both varieties (Cassman et al., 1989; Jiang et al., 2008).

There was no relationship between chlorophyll a, b and ab in the first cropping without hormones application harvested at 148 DAT and the second cropping with hormones application harvested at 90 DAT. This could be as a result of levels of hormone concentration applied twice at 36 and 67 DAT. The higher levels of the second hormones application at 67 DAT, thereafter, caused the leaves green pigment to change to yellow pigment.

\section{Conclusion}

The results of this investigation indicate a significant role of potassium $(\mathrm{K})$ at low $\left(1 \times 10^{-3}\right)$, high $(6 \times$ $\left.10^{-3} \mathrm{molL}^{-1}\right)$ levels, phosphorus $(\mathrm{P})$ at high $\left(1 \times 10^{-3} \mathrm{molL}^{-1}\right)$ level and plant hormones at concentration of 50,40 and $50 \mu \mathrm{gL}^{-1}$ for IAA, $\mathrm{GA}_{3}, \mathrm{Z}$, respectively, and $\mathrm{Z}$ at $100 \mu \mathrm{gL}^{-1}$ play in chlorophyll formation in plants. The cotton plant greenish pigment (chlorophyll $\mathrm{a}, \mathrm{b}$, and $\mathrm{ab}$ ) was noticed up to 91 DAT for the $1^{\text {st }}$ experiments without hormones application and 80 DAT for the $2^{\text {nd }}$ experiment with hormones application. The second cropping should have looked healthier than first cropping, if the second hormones application were not done at 67 DAT. Hence, the result of this present study suggests an early application of hormones at 36 DAT would be better. There is a need for hydroponics farmers to pay close attention to time and concentration of hormones so as to obtain optimum harvest.

\section{Acknowledgement}

Many thanks to Faculty of graduate study Dalhousie University, Halifax, Canada for research Scholarship. The author appreciated the collaboration study carried out with College of Natural Resources and Environmental Sciences research team of Xinjiang Agricultural University, Urumqi, China. The gratitude goes to Prof.Wang Chunli, Shen Dong and Chenboliang for the interpretation and technical support during the project.

\section{References}

Apel, K., Santel, H. J., Redlinger, T. E \& Falk, H. (1980). The protochlorophyllide holochrome of barley (Hordeum vulgare L.). Isolation and characterization of the NADPH: Protochlorophyllide oxidoreductase. Eur. J. Biochem., 111: 251-258. http://dx.doi.org/10.1111/j.1432-1033.1980.tb06100.x

Cassman, K. G., Kerby, T. A., Robert, B. A., Bryant, D. C. \& Brouder, S. M. (1989). Differential response of two cotton cultivars to fertilizer and soil potassium. Agron. J., 81:870-876. http://dx.doi.org/10.2134/agronj1989.00021962008100060006x

Dei, M. \& Tsuji, H. (1978). The influence of various plant hormones on the stimulatory action of red light on greening in excised etiolated cotyledons of cucumber. Plant Cell Physiol., 19: 1407-1414.

Duli Zhao, Oosterhuis, D. M \& Bednarz, C. W. (2001). Influence of potassium deficiency on photosynthesis, chlorophyll content and chloroplast ultrastructure of cotton plants.Photosynthetica, 39 (1): $103-109$. http://dx.doi.org/10.1023/A:1012404204910

Everitt, J. H., Richardson, A. J. \& Gausman, H. W. (1985). Leaf reflectance-nitrogen- chlorophyll relations in 
buffelgrass. Photogramm. Eng. Remote Sens., 51: 463-466.

Fletcher, R. A \& McCullagh. D, (1971). Cytokinin-Induced Chlorophyll formation in Cucumber Cotyledons.Planta (Berl), 101, 88-90. http://dx.doi.org/10.1007/BF00387693

Fletcher, R. A., Kallidumbil, V. \& Bhardwaj, S. N. (1982). Effect of fusicoccin on fresh weight and chlorophyll levels in Cucumber cotyledons. Plant \& cell physiol., 23 (4): 717-719.

Ford, M., Black, M. and Chapman, J. M. (1977). Inter-organ synergism and the control of chlorophyll accumulation in sunflower (Hclianthus annuus) cotyledons. J. Exp. Bot., 28: 926-934. http://dx.doi.org/10.1093/jxb/28.4.926

Fridgen, Jennifer L. \& Varco, Jac J. (2004). Dependency of Cotton Leaf Nitrogen, Chlorophyll, and Reflectance on Nitrogen and Potassium Availability. Agron. J., 96: 63-69. http://dx.doi.org/10.2134/agronj2004.0063

Griffiths, W.T. (1978). Reconstitution of chlorophyllide formation by isolated etioplast membranes. Biochem. J., 174: 681-692.

Jiang Cun-cang, Chen Fang, Gao Xiang-zhao, Lu Jian-wei, Wan Kai-yuan, Nian Fu-Zhao \& Wang Yun-hua (2008). Study on the nutrition characteristics of different K use efficiency cotton genotypes to K deficiency stress.Agricultural Sciences in China, 7 (6): 740-745. http://dx.doi.org/10.1016/S1671-2927(08)60109-1

Koski, V. M., French, C. S \& Smith, J. H. C (1951). The action spectrum for the transformation of protochlorophyll to chlorophyll $a$ in normal and albino corn seedlings. Arch. Biochem., 31: 1-17. http://dx.doi.org/10.1016/0003-9861(51)90178-6

Lamrani, Z., Belakbir, A., Ruiz, J. M. Ragala, L., Lopez-Cantarero, I. \& Romero, L. (1996). Influence of nitrogen, phosphorus, and potassium on pigment concentration in cucumber leaves. Commun. Soil Sci. Plant Anal., 27: 1001-1012. http://dx.doi.org/10.1080/00103629609369613

Longstreth, D. J., \& Nobel, P. S (1980). Nutrient influences on leaf photosynthesis. Effects of nitrogen, phosphorus, and potassium for Gossypium hirsutum L. Plant Physiol., 65: 541-543. http://dx.doi.org/10.1104/pp.65.3.541

Maples, R. L., Thompson, W. R. Jr., \& Varvil, J. (1988). Potassium deficiency in cotton takes on a new look. Better Crops Plant Food, 73:6-9.

Oosterhuis, D. M. \& Bednarz, C. W. (1997). Physiological changes during the development of potassium deficiency in cotton. p. 347-351. In T. Ando et al., (ed.) Plant nutrition for sustainable food production and environment. Kluwer Academic Publ., Dordrecht, the Netherlands. http://dx.doi.org/10.1007/978-94-009-0047-9_102

Roger, L \& Hideo, T. (1982). Effect of Benzyladenine Treatment Duration on \%-Aminolevulinic Acid Accumulation in the Dark, Chlorophyll Lag Phase Abolition, and Long-Term Chlorophyll Production in Excised Cotyledons of Dark-Grown Cucumber Seedlings. Plant Physiol., 69: 663-667. http://dx.doi.org/10.1104/pp.69.3.663

Stromberg, L.K. (1960). Need for potassium fertilizer on cotton determined by leaf and soil analysis. Calif. Agric., 14: 4-5.

Thomas, J. R. \& Gausman. H. W (1977). Leaf reflectance vs. leaf chlorophyll and carotenoid concentrations for eight crops. Agron. J., 69: 799-802. http://dx.doi.org/10.2134/agronj1977.00021962006900050017x

Uheda, E. \& Kuraishi, S. (1977). Increase of cytokinin activity in detached etiolated cotyledons of squash after illumination. Plant \& Cell Physiol., 18: 481-483.

Yoshiki Yamaryo, Daisuke Kanai, Koichiro Awai, Mie Shimojima, Tatsuru Masuda, Hiroshi Shimada, Ken-ichiro Takamiya \& Hiroyuki Ohta. (2003). Light and Cytokinin Play a Co-operative Role in MGDG Synthesis in Greening Cucumber Cotyledons. Plant and Cell Physiology, Vol. 44, No. 8: 844-855. http://dx.doi.org/10.1093/pcp/pcg110 
Table 1. Hydroponic nutrient composition

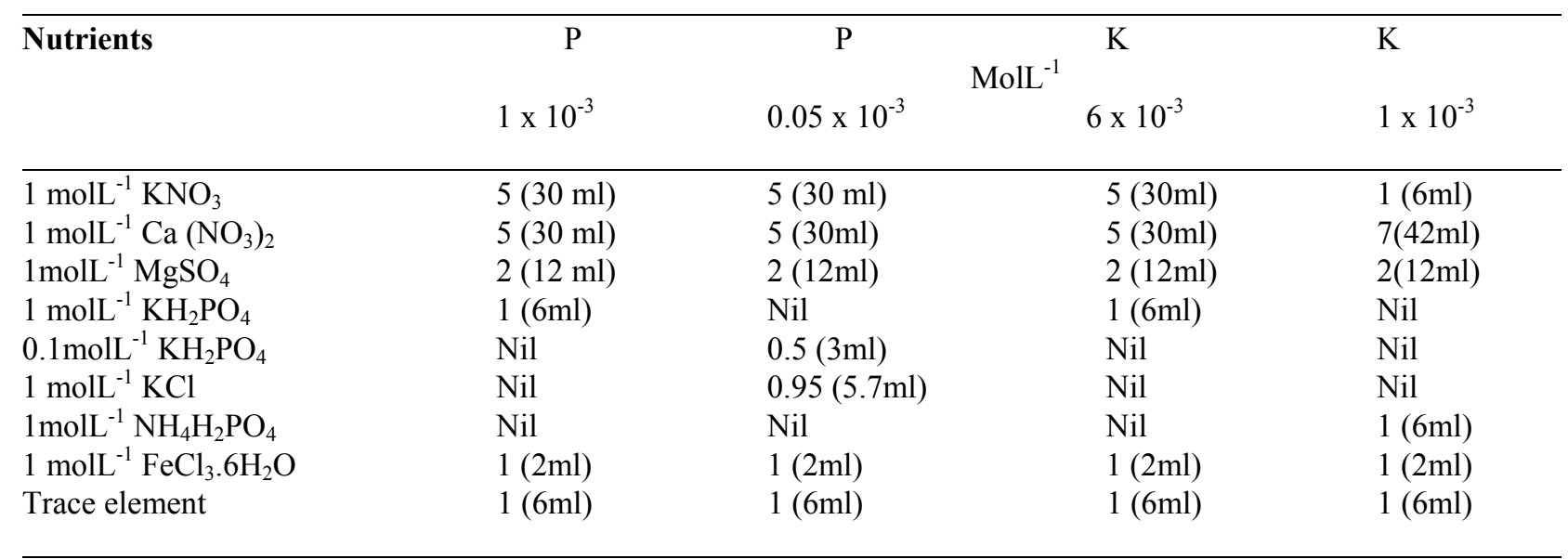

P-Phosphorus

K-Potassium

Table 2. The chlorophyll A content of cotton plants grown hydroponically treated to phosphorus, potassium and their combinations

\begin{tabular}{|c|c|c|c|c|c|}
\hline \multirow[b]{2}{*}{ Treatments } & \multicolumn{3}{|c|}{$\begin{array}{l}\text { CHLOROPHYLL a }\left(\mu \text { gml }^{-1}\right) \\
\text { DAT }\end{array}$} & \multirow[b]{2}{*}{120} & \multirow[b]{2}{*}{148} \\
\hline & 83 & 91 & 104 & & \\
\hline Low $P$ & $0.456 \mathrm{~b}$ & $0.504 b$ & $1.76 \mathrm{a}$ & $1.24 \mathrm{a}$ & $1.02 \mathrm{a}$ \\
\hline Low $\mathrm{K}$ & $1.23 \mathrm{ab}$ & $1.76 \mathrm{a}$ & $0.727 \mathrm{a}$ & $1.76 \mathrm{a}$ & $0.989 a$ \\
\hline High PK & $1.92 \mathrm{a}$ & $1.90 \mathrm{a}$ & $2.39 \mathrm{a}$ & $1.07 \mathrm{a}$ & $0.673 a$ \\
\hline $\mathrm{SE}$ & 0.453 & 0.351 & 0.860 & 0.458 & 0.335 \\
\hline
\end{tabular}

SE-Standard Error .Means within columns followed by the same letter are not significantly different at $\mathrm{P}=0.05$ according to Duncan's multiple range test.

Table 3. The chlorophyll B content of cotton plants grown hydroponically treated to phosphorus and potassium and their combinations

\begin{tabular}{llllll}
\hline \multicolumn{5}{c}{ CHLOROPHYLL $\mathrm{b}\left(\mu \mathrm{gml}^{-1}\right)$} \\
Treatments & 83 & 91 & 104 & 120 & 148 \\
\hline Low P & $0.084 \mathrm{~b}$ & $0.227 \mathrm{~b}$ & $0.979 \mathrm{a}$ & $0.631 \mathrm{a}$ & $0.185 \mathrm{a}$ \\
Low K & $0.635 \mathrm{a}$ & $1.22 \mathrm{a}$ & $0.415 \mathrm{a}$ & $0.876 \mathrm{a}$ & $0.216 \mathrm{a}$ \\
High PK & $0.636 \mathrm{a}$ & $1.29 \mathrm{a}$ & $0.402 \mathrm{a}$ & $0.537 \mathrm{a}$ & $0.015 \mathrm{a}$ \\
SE & 0.195 & 0.239 & 0.436 & 0.206 & 0.123 \\
\hline
\end{tabular}

SE-Standard Error .Means within columns followed by the same letter are not significantly different at P $=0.05$ according to Duncan's multiple range test. 
Table 4. The chlorophyll AB content of cotton plants grown hydroponically treated to phosphorus and potassium and their combinations

\begin{tabular}{llllll}
\hline \multicolumn{5}{c}{ CHLOROPHYLL ab $\left(\mu \mathrm{gml}^{-1}\right)$} \\
\hline Treatments & 83 & 91 & 104 & 120 & 148 \\
Low P & $0.540 \mathrm{~b}$ & $0.731 \mathrm{~b}$ & $2.74 \mathrm{a}$ & $1.87 \mathrm{a}$ & $1.21 \mathrm{a}$ \\
Low K & $1.87 \mathrm{a}$ & $2.97 \mathrm{a}$ & $1.14 \mathrm{a}$ & $2.64 \mathrm{a}$ & $1.21 \mathrm{a}$ \\
High PK & $2.56 \mathrm{a}$ & $3.20 \mathrm{a}$ & $2.79 \mathrm{a}$ & $1.61 \mathrm{a}$ & $0.688 \mathrm{a}$ \\
SE & 0.615 & 0.495 & 0.882 & 0.658 & 0.429 \\
\hline
\end{tabular}

SE-Standard Error .Means within columns followed by the same letter are not significantly different at $\mathrm{P}=0.05$ according to Duncan's multiple range test.

Table 5. Effect of hormones concentration on chlorophyll content of cotton plants grown hydroponically in high level of PK

\begin{tabular}{|c|c|c|c|c|c|c|c|}
\hline \multirow[b]{2}{*}{ Treatments } & \multirow[b]{2}{*}{$\mathrm{a}$} & \multirow[t]{2}{*}{80} & \multicolumn{5}{|c|}{ CHLOROPYLL $\left(\mu \mathrm{gml}^{-1}\right)$} \\
\hline & & & $\mathrm{b}$ & $a b$ & a & $\mathrm{b}$ & $\mathrm{ab}$ \\
\hline Control & $0.798 \mathrm{~cd}$ & & $0.327 \mathrm{de}$ & $1.13 b c$ & $1.34 \mathrm{a}$ & $0.716 \mathrm{a}$ & $2.05 \mathrm{a}$ \\
\hline IAA & $2.53 \mathrm{a}$ & & $1.23 \mathrm{ab}$ & $3.76 \mathrm{a}$ & $0.783 \mathrm{ab}$ & $0.489 \mathrm{ab}$ & $1.27 \mathrm{ab}$ \\
\hline $\mathrm{GA}_{3}$ & $1.62 \mathrm{abc}$ & & $0.933 \mathrm{abc}$ & $2.55 \mathrm{ab}$ & $0.261 \mathrm{~b}$ & $0.196 \mathrm{~b}$ & $0.457 \mathrm{~b}$ \\
\hline Z & $2.48 \mathrm{a}$ & & $1.27 \mathrm{ab}$ & $3.75 \mathrm{a}$ & $0.473 b$ & $0.307 \mathrm{~b}$ & $0.783 b$ \\
\hline IAA $x \mathrm{GA}_{3} \times \mathrm{Z}$ & $0.670 \mathrm{~cd}$ & & $0.407 \mathrm{cde}$ & $1.08 \mathrm{bc}$ & $0.409 \mathrm{~b}$ & $0.193 b$ & $0.561 \mathrm{~b}$ \\
\hline 2IAA $x \mathrm{GA}_{3} \times \mathrm{Z}$ & $0.209 \mathrm{~d}$ & & $0.149 \mathrm{e}$ & $0.359 \mathrm{c}$ & $0.910 \mathrm{ab}$ & $0.377 \mathrm{~b}$ & $1.29 \mathrm{ab}$ \\
\hline IAA $\times 2 \mathrm{GA}_{3} \times \mathrm{Z}$ & $1.05 \mathrm{~cd}$ & & 0.491 cde & $1.54 \mathrm{bc}$ & $0.342 \mathrm{~b}$ & $0.206 \mathrm{~b}$ & $0.549 \mathrm{~b}$ \\
\hline IAA $\times G_{3} \times 2 Z$ & $2.33 \mathrm{ab}$ & & $1.46 \mathrm{a}$ & $3.79 \mathrm{a}$ & $0.514 b$ & $0.329 \mathrm{~b}$ & $0.843 b$ \\
\hline 2 IAA $\times 2 \mathrm{GA}_{3} \times 2 \mathrm{Z}$ & $1.34 \mathrm{bc}$ & & $0.732 \mathrm{bcd}$ & $2.08 \mathrm{~b}$ & $0.328 \mathrm{~b}$ & $0.259 \mathrm{~b}$ & $0.587 \mathrm{~b}$ \\
\hline SE & 0.476 & & 0.256 & 0.708 & 0.298 & 0.160 & 0.446 \\
\hline
\end{tabular}

SE-Standard Error. Means within columns followed by the same letter are not significantly different at $\mathrm{P}=0.05$ according to Duncan's multiple range test.

Table 6. Correlation co- efficient relating low P, low K and high PK plant treatments at 148 days after transplanting to hormones plant treatments at high level of $\mathrm{PK}$ at 90 days after transplanting

\begin{tabular}{ll}
\hline Chlorophyll Content & $\begin{array}{l}\text { Correlation Co-efficient }(\mathrm{r}) \text { relating low P, low K and high PK } \\
\text { to hormones applied }\end{array}$ \\
\hline$\left(\mu \mathrm{gml}^{-1}\right)$ & $0.188 \mathrm{~ns}$ \\
A & $-0.005 \mathrm{~ns}$ \\
B & $0.114 \mathrm{~ns}$ \\
AB & \\
ns-not significant & \\
\hline
\end{tabular}




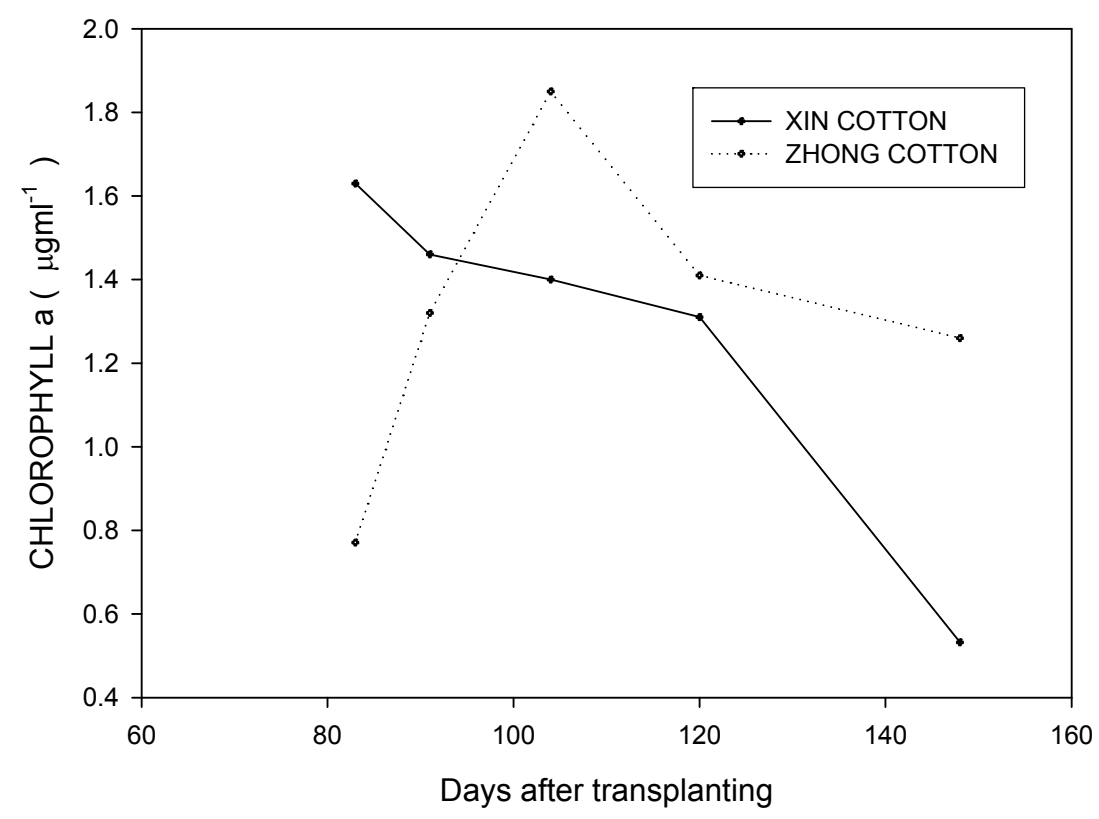

Figure 1a. The chlorophyll a content of cotton plant varieties grown hydroponically treated to phosphorus, potassium and their combination

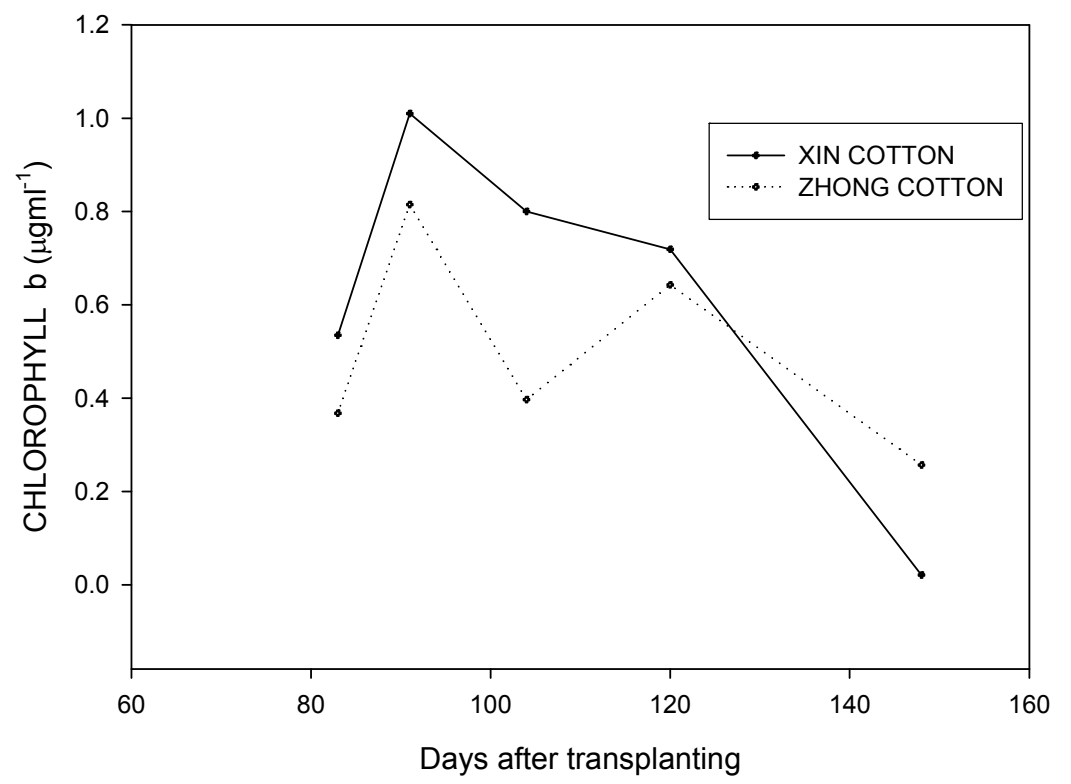

Figure $1 \mathrm{~b}$. The chlorophyll $\mathrm{b}$ content of cotton plant varieties grown hydroponically treated to phosphorus and potassium and their combination 


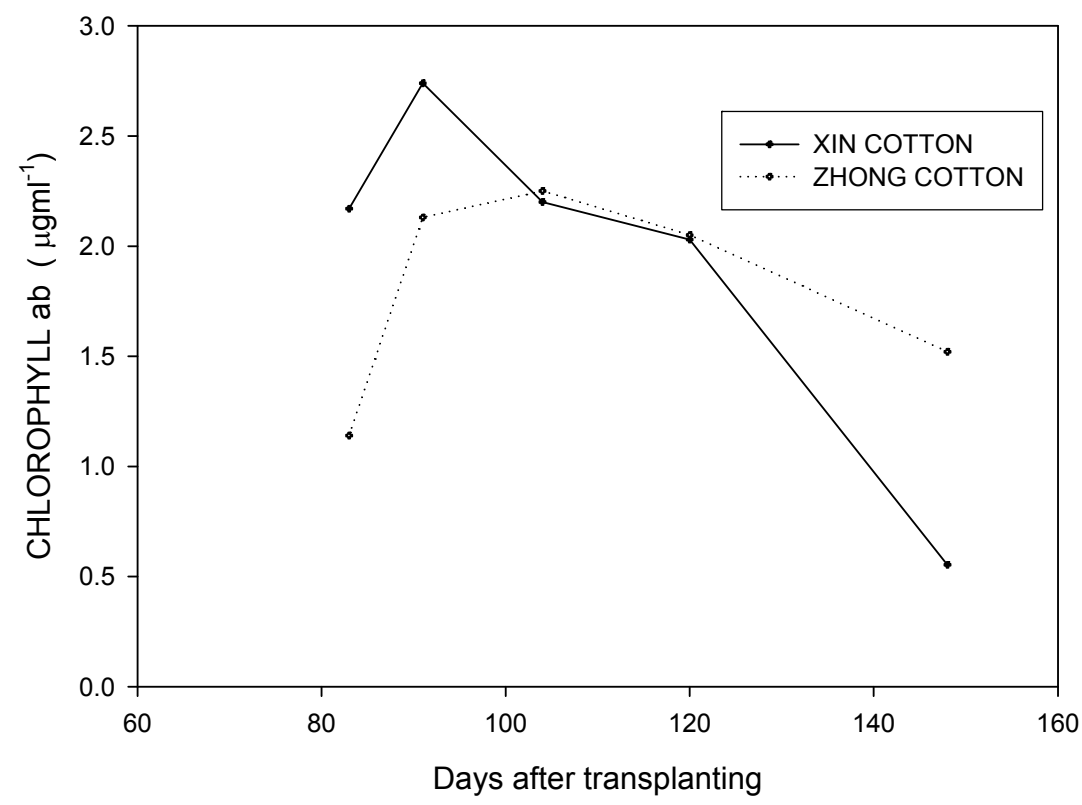

Figure 1c. The chlorophyll ab content of cotton plant varieties grown hydroponically treated to phosphorus and potassium and their combination

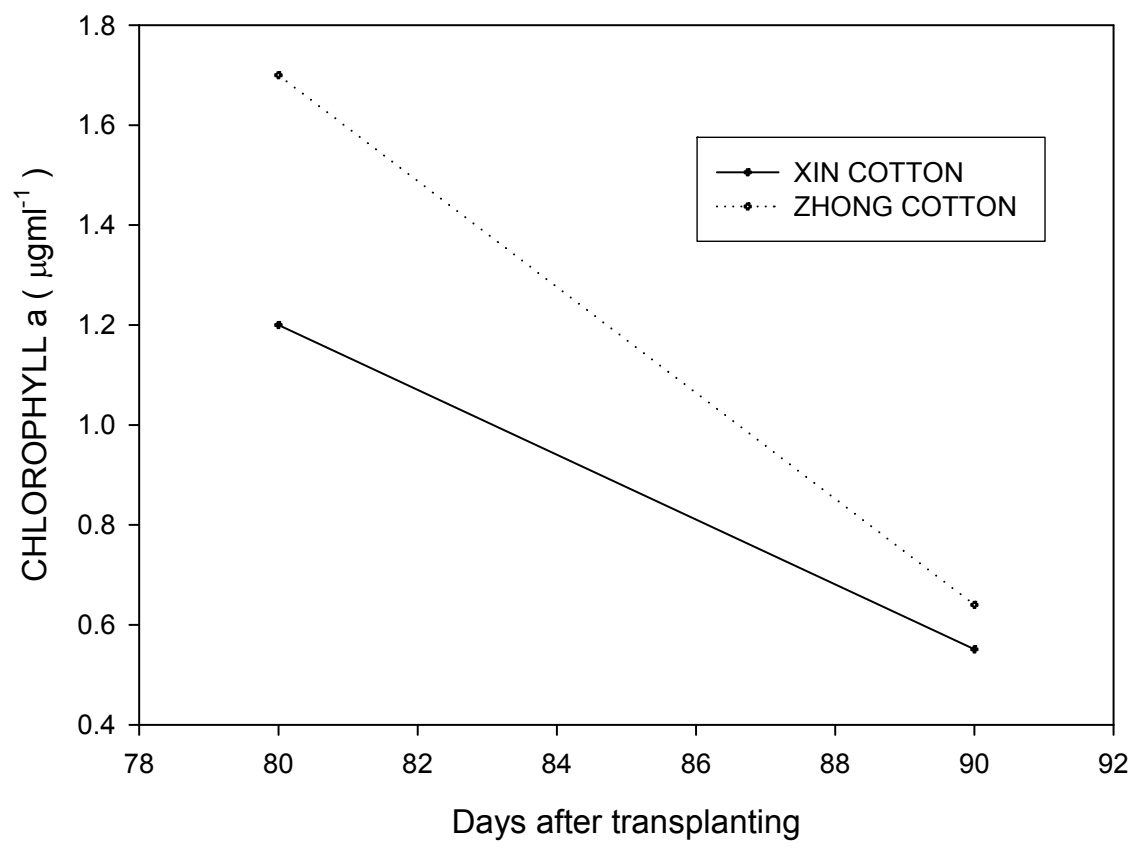

Figure 2a. Effect of hormones concentration on chlorophyll a content of cotton varieties grown hydroponically in high level of PK 


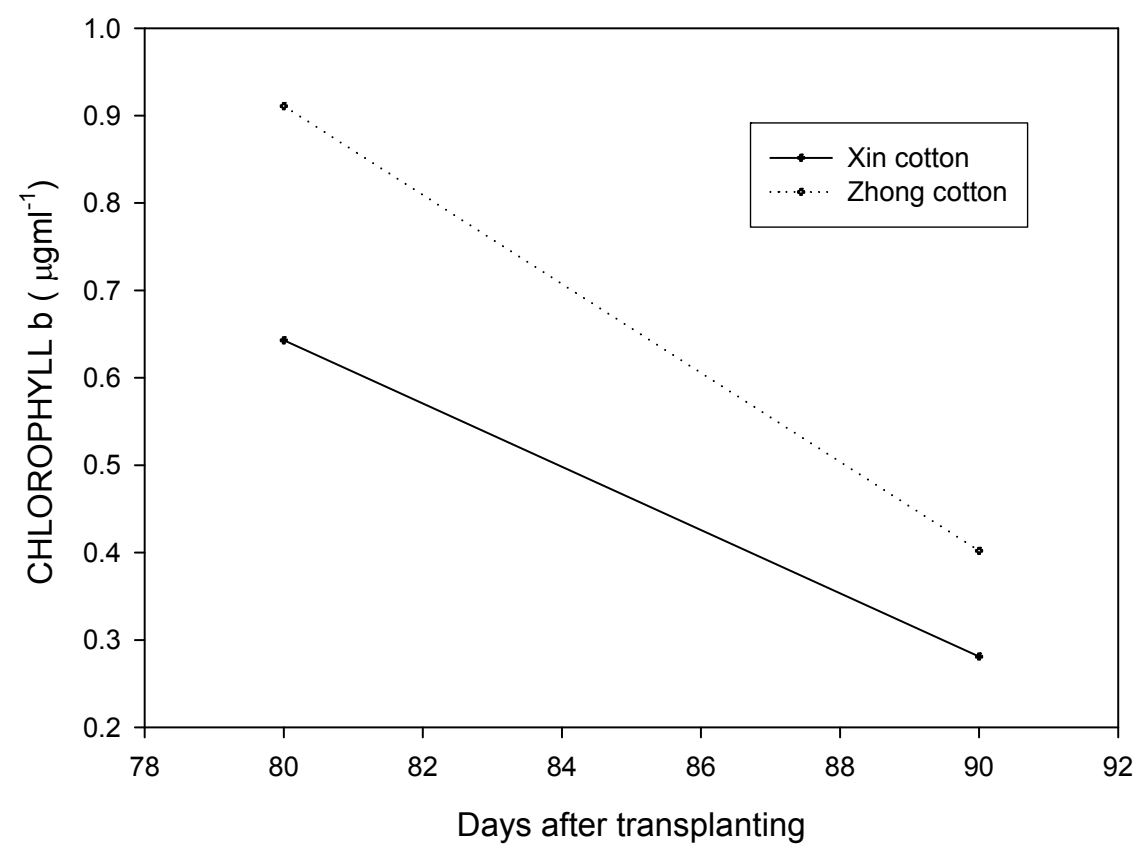

Figure $2 \mathrm{~b}$. Effect of hormones concentration on chlorophyll $\mathrm{b}$ content of cotton varieties grown hydroponically in high level of PK

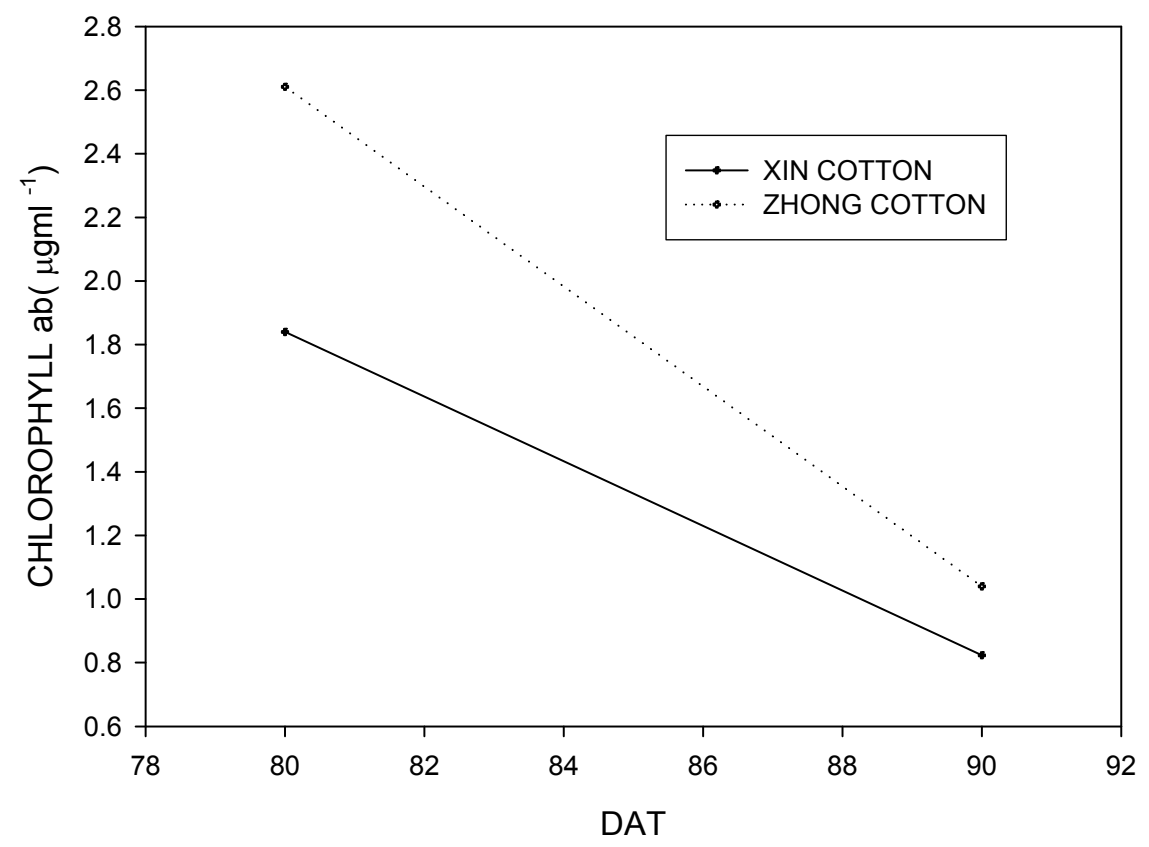

Figure 2c. Effect of hormones concentration on chlorophyll ab content of cotton varieties grown hydroponically in high level of PK 